\title{
Mediation Effect of the Organizational Culture on the Relationship between Perceived Ethics on Performance of SMEs
}

\author{
Abdullahi Hassan Gorondutse (iD), Haim Hilman (iD) \\ School of Business Management. College of Business, Universiti Utara Malaysia (Malaysia) \\ abdullabi@uum.edu.my, bilman@,uum.edu.my
}

Received: January 2016

Accepted: May 2016

\section{Abstract:}

Purpose: This research aims to examine the association between perceived ethics and SMEs performance; also determine the mediation effect of organizational culture on the relationship.

Design/methodology/approach: Based on the literature review, this research developed a conceptual model of Perceived ethics, organizational culture and performance. This research applied purposive sampling to gather data from owners/managers of SMEs in Kano State NorthWest of Nigeria. Apart from assessing the reliability and validity of the constructs through confirmatory factor analysis, this research also used Partial Least Square Techniques (PLS) of analysis approach to test the proposed hypothesis.

Findings: Statistical result reveals that the relationship between perceived ethics and SMEs performance was found to be significant at p.value less than 0.001. Similarly as postulated the organizational culture mediates the relationships with significant value.

Research limitations/implications: The sample for this study is based on SMEs and cross sectional in nature, In addition, the present study employed quantitative techniques future study can employed qualitative or case study method for design and analysis of information

Practical implications: The finding of this study can assist practitioners and policy makers in SMEs to support the idea of social responsibility in designing strategic plan for superior 
performance. As whole, the outcome of this research will assist managers for better understanding of the business social responsibility antecedents under the perspective SMEs.

Originality/value: This paper has tried to provide a comprehensive understanding about business social responsibility antecedents under the perspective SMEs context in Nigeria. Since there was a lack of such research in SMEs context, this research can provide theoretical contribution and managerial basis for future researches as well as implications for the managers.

Keywords: perceived ethics, organizational culture, SMEs performance and Nigeria

\section{Introduction}

Perceived ethics is a business adoption desired ethical standard and practices, some business encourage an ethical culture by establishing positive values that influence organization members, ethical believes and actions (Jin \& Drozdenko \& Deloughy, 2013; Trevino \& Nelson, 2004; Valentine \& Fleischman, 2008), other business advance organization ethics with codes that provide ethical values and behavioral requirement (Valentine \& Fleischman, 2004, 2008). Similarly, some business recognized training to provide workers guidance about ethics (Jin \& Drozdenko, 2010; Jin et al., 2013; Perrini \& Minoja, 2008; Valentine \& Fleischman, 2008).

BSR can fulfill a business' commitment in offer attractive services for its workforce (Cacioppe et al., 2008; Peloza \& Papania, 2008). Earlier studies have also proven that a firm's ethics yields better work pleasure and organizational performance (Berrone, Surroca \& Tribo, 2007; Deshpande. \& Farley, 1999; Jin et al., 2013; Koh \& Boo, 2001; Peloza \& Papania, 2008; Singhapakdi, Kraft, Vitell \& Rallapalli, 1995; Vitell \& Davis, 1990). Similarly, it has been observed that a link exists with regards to business ethics and BSR (Hilman \& Gorondutse, 2013; Peloza \& Papania, 2008; Singhapakdi et al., 1995), with firm performance.

Today, company in society has been provoked by improved feelings to the consciousness of ethical and environmental issues (Valentine \& Fleischman, 2008). This means that public have develop into more care that greater pressure and development by corporation has not been accompanied by the same attempt and wish in addressing vital issues including problem of shortage of resources, drug misuse, offences, inappropriate behaviour of employees, defective creation of production and ecological harm or toxic waste by the industries as it has eventually been reported in the media (Amaeshi, Adi, Ogbechie \& Amao, 2006; David, 2012). 
Consequently, it is necessary for all businesses to recognize that society requires better - social responsibility; good image may vanish if business organizations fail to react to the challenges these ethical issues may cause to society (David, 2012). Very few empirical researches have directly investigated BSR from an organizational or workers point of view, both with regards to how workers' see the social performance of their company or how BSR perceptions affect their everyday morals and behaviors (Aguilera, Ruth, Rupp, Williams \& Ganapathi, 2007; Hansen, Dunford, Alan, Boss, Boss \& Angermeier, 2011). Regrettably, however, very few empirical researches' has directly investigated perceived ethics from an organizational or workers point of view, both with regards to how workers see the social performance of their company or how business ethics perceptions affect their everyday morals and behaviors (Aguilera et al., 2007; Hansen et al., 2011).

In addition, despite many researches on BSR and performance link, there is general agreement that the association is still not well understood (Zaborek, 2014), Even though diverse attempts by organization to convene anticipation of stakeholders yet this responsible behavior has not been addressed hence led to call for a different way to make clear the association between the BSR and managerial performance (Berrone et al., 2007; Peloza \& Papania, 2008; Perrini \& Castaldo, 2008; Pivato, Misani \& Tencati, 2008). Additionally, due to increase emphasis on BSR from local and world business issue of organizational culture can be incorporated to investigate the influence of various cultures on the value of BSR strategies (Gorondutse \& Hilman, 2014; Fang, Huang \& Stephanie, 2010). In line with this considering theoretical linkage between managerial factors such as perceived ethics and meditational effect of organizational culture has been seen few or no tested proof to SMEs performances to date, this study undertaken to logically consider the potential mediating role of organizational culture in the perceived ethicsperformance relation on SMEs.

However, most of the Nigerian firms are insensitive with the social responsibility particularly in Kano State, which is the largest city and centre of commerce of the country. Previous studies in Nigeria have given emphasis on multinational companies (Adegbite \& Chizu, 2011; Amaeshi et al., 2006; David, 2012; Ite, 2004, 2005; Opara, 2010; Okoye, 2009). Therefore, this study will look at the relationship between perceived ethics and organizational performances of indigenous firms (local environment) with mediating role of organizational culture. SMEs account for more than 90\% of the world's business enterprises, and SMEs and provide self employment nearly $70 \%$ of the sum engaged labor force (European Commission, 2003). There are diversity of gaps in the issue of social responsibility and SMEs research (Cochet \& Chi, 2012). in Nigeria the paramount estimates obtainable recommend that SMEs constituted $87 \%$ of all business functioning in Nigeria, despite that the total figure of registered business in Nigeria is also unidentified (World Bank, 2005). Generally, it shows very few or no empirical based research on what might be the consequence on relations to that issue as mentioned earlier on organizational performance. Therefore, this paper aims to fill the paucity of this research in the newer context Nigeria. 
The remainder of this paper will be organized as follows. Next, a literature reviewed on perceived ethics and performance is highlighted. Then, previous works that relate the concepts are presented toward the development of a model that explains the relationships, to link these relationships stakeholder theory is used as a root. Third section discusses on methodology and hypothesis to be tested, next is the discussion and analysis of result, and finally, conclusion, recommendations and limitation for future study.

\section{Literature Review}

\subsection{Relationships between Perceived Ethics and Performance}

Managerial ethics is a firms embracing of beloved ethical principles and business practices. Some firms encourage an ethical culture/climate by providing significant principles that persuade organizational members' ethical way of life and measures (Trevino \& Nelson, 2004). Other firms advance organizational ethics with regulations that here ethical standards and behavioral necessities. A usual expansion of organizational ethics is a business's participation in BSR, which includes responding the necessities of stakeholders, with exacting concentration on community issues and opportunities Joyner and Payne (2002), it is consequently stands to basis that ethics activities not only increase a company's ethical social culture, but also its consideration to BSR other ethics programs should also enhance a firms performances (Berrone et al., 2007; Sen \& Bhattacharya, 2001; Singhapakdi et al., 1995). Previous studies found relationship between perceived ethics and financial performances to be positive (Waddock $\&$ Cranes, 1997).

There has been a substantial argument on the association between business social responsibility and business performance measures. Carroll and Shabana (2010) reviewed the literature on the business case for BSR and finalized that there is proof of a relationship between BSR and corporate financial performance (Jin et al., 2013). Similarly, Mackey, Mackey and Barney (2007) were argue that business should sometimes invest in socially responsible behaviors even though those behavior might reduce the business liquidity, and present a speculation that shows how publicly traded organizations might still benefit from an increase to the market value of the firm despite the expenses resulting from implementing social programs (Jin et al., 2013).

However, Aupperle, Carroll and Hatfield (1985) and Coffey and Fryxell (1991), found there are no relationships or mixed results and method used varied and Contentious (Verschoor, 1998). Despite that, other studies use perceives ethics \& performances in the perspective of customer and there is inconsistence in the results (Tian, Wnag \& Yang, 2011; Stanaland, Lwin \& Murphy, 2011; Peng-Lin et al., 2011; Valentine \& Fleischman, 2008). Base on the above, this study tests the relationships on the organization perspectives and will look at both financial and non financial aspect of Performance 
measurement. And this relation is in line with stakeholder theory which states that managers should tailor their policies in order to satisfy a number of stakeholders (Freeman, 1984). Hence, this posit hypothesis below:

\section{H1: Perceived ethics is significantly related to Performance.}

\subsection{Relationships between Organizational Culture and Performance}

According to Schein (1992), organizational culture is the main and common diverse issue in the globe due to cultural difference among the nations as well as for organizations, and has been every time an essential construct in management and business research for many years due to its capability to impact organizational outcomes. Schein (1992), model of organizational culture showed its diverse stages including norms and principles which have an effect on the organizational performance indifferent angles. The constructive culture of the organization affects the organizational performance in significant directions and takes it to the success. The organizational culture mainly determined on the leadership/management's commitment and participation in the organizational works (Lok \& Crawford, 1999).

Organizational culture educates the populace about the accomplishment of the objectives within the organization. So an organizational culture is connecting which direct the workers how to influence and respond with respect to their abilities (Nancy \& Galanaki, 2008). Therefore, it must be an equivalent linking organizational culture, leadership efficiency and organizational performance (Dag, 2006). Furthermore A key to good performance is a strong culture, a significant and strong culture can make an organization to achieve excellent, where as negative and weak culture may lead to few performances and at end no achievement (Ahmad, Veerapandian \& Ghee, 2011).

Furthermore, previous researches have also reveals that organizational culture has an effect on organizational performances (Shah, Iqbal, Yameen, Sabir \& Khan, 2011; Larry, Morgan \& Douglas, 2011; Rashid, Sambasivan \& Johari, 2003). Although their situation is quite diverse from this research, Base on the above, it assumes that organizational culture played a vital role in promoting organizational success, and this could only achieved by putting a desire culture which shaped organization managers values, attitude and behavior (Rashid et al., 2003). Additionally, organizational culture and it relationship to performance, Therefore, it is possible for organizational culture as a mechanism or process to mediates the relationship between BSR and performance. The influence of moral values and perceived ethical of the corporate culture is not consistent; hence additional study considered organizational influence is needed (Herndon, Fraedrich \& Jen-yeh, 2001). It's expected that this study will clarify the previous finding and contribute to general management knowledge using the stakeholder theory (Jones, 1995), and 
which states that managers should tailor their policy to satisfy numerous constituents, and incorporate ethical culture in all aspects of the business activities (Freeman, 1984; Wood, 2002). Thus, this leads to the following hypotheses:

H2: organizational culture is significantly related to performance.

H3: Organizational culture mediates the relationship between perceived ethics and performance.

\subsection{Underpinning Theory of Stakeholder}

Many explanation of stakeholder theory has been predictable, but the contract is that it can be useful to give details as well as to direct the arrangement and operations of the reputable organizations (Donaldson \& Preston, 1995). Therefore, this is not only to say that business have take action in a conscientious way to equivocate escalating stakeholder demands, but to accomplish a better or excellent community. In addition, Jones (1995) argued that business concerned frequent dealings with stakeholders on the foundation of trust and cooperation has a motivation to be honest and ethical, since such behavior is advantageous to business (Jones, 1995).Hence, this relationship is in line with stakeholder theory which believes that managers should tailor their policies in order to satisfy a number of stakeholders (Freeman, 1984).

Several interpretation of stakeholder theory has been projected, but the convention is that it can be useful to give details as well as to direct the arrangement and operations of reputable organizations (Donaldson \& Preston, 1995). Consequently, this is not only to say that businesses have to take action against escalating stakeholder demands, but to be part in the development of better or excellent community. In addition, it is understood that BSR actions is about the concluding end or consequence from course of action but all process that exist throughout the entire management levels (Jones, 1995). In addition, Jones (1995) argued that businesses have frequent dealings with stakeholder's base on the foundation of trust and cooperation has a motivation to conduct and behave ethically, since such behavior give advantages to business.

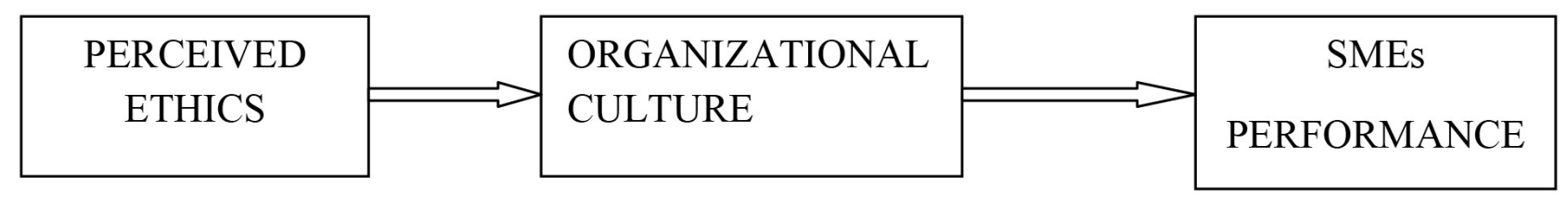

Figure 1. Research framework 


\section{Methodology}

The research method is cross-sectional study design and non-experimental using the quantitative method of running questionnaire. The study unit analysis was owner/manager. The population during the study was 29, 204 and required samples sizes is 394 in conjunction of Yamane (1967) sample selection formulae. In order to reduced the sample sizes error and take care of the non response problem, the sample size were doubling and round up to 800 (Hair, Wolfinbarger \& Ortivian, 2008). In multivariate research, the sample size should be ten (10) times as large for the number of variables for the study. A purposive samples technique was used to draw a population samples through survey method using self Administration questionnaire method with the help of research assistances.

Moreover, measurement of this study was adapted from the study conducted by (Curras-Pérez, Bigne \& Herrera, 2009; Lin, Chen, Chiu \& Lee, 2011; Kaplan \& Norton, 1992; Venkatraman \& Ramanujam, 1986; Wallach, 1983), with little contextual modification that fit the environment of study to measure the control on the independent construct (perceived ethics) and dependent construct (performance) using 7point type, a scale with midpoint provide better optimal results in information processing and scale reliability, in addition, the 7-point scale is said to be efficient (Cavana, Delahaye \& Sekaran, 2001; Churchill \& Peter, 1984). The data collected were analyzed using SPSS version 18 and SEM-PLS software which provide consistent data that reflect the theory. It has been reported that PLS SEM can account for measurement error and can present more precise calculations of moderation effects (Chin, 1998a) and feasible alternatives of testing mediation (Chin, Marcolin \& Newsted, 2003). Additionally, PLS path modeling is becomes more suitable for real world applications, suitable for better prediction and more beneficial to use when models are complex (Hulland, 1999) and address the problem of statistical power with analysis (Haenlein \& Kaplan, 2011). The soft modeling assumptions of PLS method (i.e., ability to be flexible develop and validate complex models) gives it the benefit of estimating large complex models (Akter, Ambra \& Ray, 2011), PLS path modelling does not necessarily require data to be normal (Chin, 1998a). In other words, PLS treats non-normal data relatively well, by and larger.

\subsection{Common Method Bias}

CMV is ascertained is ascertained when constructs are measured using cross sectional survey technique, in order to tackle with this issue the study applied Harman 1-factor test on 3 constructs' and the results reveals that no significant biases in the data. In addition, the correlation matrix (Table 5) does not signify any extremely correlated variables; common method bias frequently results in tremendously high correlations (r, 0.90) (Bagozzi, Yi \& Phillips, 1991). Consequently, we may assume that common method 
variance bias is not a problem, and the results corroborate the tenability of the proposed measurement model.

\section{Research Findings}

Out of 800 questionnaires distributed 514 were returned out of which 486 are usable and valid for analysis after taken consideration of missing values and outliers with extreme values which yield the response rate 64\%. According to Tabachnik and Fidell (2007) a response rate considered sufficiently large for statistical reliability and generability. The data collection took almost 5 month after a series of follow up during the period; errors were checked by statistical analysis for all the constructs cases.

\subsection{Demographic of Respondents}

The descriptive analysis reveals that 31.1\% were General Manager, 29.8\% were different categories of Managers and 29.4\% were Chief executive/Owner of business. Descriptive statistic show that the respondents were less than 5 years of their existence in the business with $35 \%$, followed by the range of 5-10 years, which was 32.5\%; followed by the range bracket of $11-20$ years with $22.6 \%$; the range bracket of $21-40$ years with $7.4 \%$, and, finally the range bracket of 40 years and above with $2.5 \%$. It can be clearly seen that most of the respondents, over $80 \%$, are still within the range of target of this study (see Table 1 for this and the subsequent descriptive statistic).

Furthermore, the descriptive statistic shows that the activities of business were more with Food and Beverages with 25.5\%, followed by Poultry with 20\%; then Textile Materials with $13.6 \%$, Weaving \& Dying with 10.7\%, Furniture and Equipment with 10.5\%, Others with 8.2\%, Recycling with 7\% and Tobacco Product with 4.5\%. The initial analysis assesses the Total Assets of the respondents based on the activities they operate. It was reveals that close to the half of the respondents 1- 100 million (1 million naira is equivalent to USD 6250), precisely $43.8 \%$, followed by less than 1 million with $34.6 \%$, followed by 101-200 million with $10.7 \%$, followed by $201-300$ million and 301 -Above with $5.8 \%$ and $5.1 \%$, respectively. 301- Above is the least among Total Assets of the business by the respondents. These perhaps indicate that the businesses are small in nature. Based on the above, it could be summarized that the respondents who participated in the research provided adequate variance regarding their backgrounds. Hence, the data used in the study were provided by respondents from diverse economic backgrounds (see Table 1, for more details). 


\begin{tabular}{|c|c|c|c|}
\hline $\mathrm{S} / \mathrm{N}$ & Items & Frequency & Percentage \\
\hline 1 & $\begin{array}{l}\text { Job Title: } \\
\text { Chief executive /owner } \\
\text { General Manager } \\
\text { Managers } \\
\text { Others }\end{array}$ & $\begin{array}{r}151 \\
160 \\
153 \\
50\end{array}$ & $\begin{array}{r}29.4 \\
31.1 \\
29.8 \\
9.7\end{array}$ \\
\hline 2 & $\begin{array}{l}\text { Years of Existence: } \\
\text { Less than } 5 \text { years } \\
5-10 \text { years } \\
11-20 \text { years } \\
21-40 \text { years } \\
\text { Above } 40 \text { years }\end{array}$ & $\begin{array}{r}180 \\
167 \\
116 \\
38 \\
13\end{array}$ & $\begin{array}{r}35 \\
32.5 \\
22.6 \\
7.4 \\
2.5\end{array}$ \\
\hline 3. & $\begin{array}{l}\text { Organization Location: } \\
\text { Headquarters } \\
\text { Division } \\
\text { Subsidiary } \\
\text { Others }\end{array}$ & $\begin{array}{r}329 \\
92 \\
43 \\
50\end{array}$ & $\begin{array}{r}64 \\
17.9 \\
8.4 \\
9.7\end{array}$ \\
\hline 4 & $\begin{array}{l}\text { Ownership of the Organization: } \\
\text { Individual } \\
\text { Partnership } \\
\text { Joint ventures } \\
\text { Others }\end{array}$ & $\begin{array}{r}247 \\
168 \\
62 \\
37\end{array}$ & $\begin{array}{r}48.1 \\
32.7 \\
12.1 \\
7.2\end{array}$ \\
\hline 5 & $\begin{array}{l}\text { Number of employee in your organization: } \\
\text { Less than } 20 \\
21-40 \\
41-60 \\
61-80 \\
\text { Above } 80\end{array}$ & $\begin{array}{r}271 \\
91 \\
39 \\
66 \\
47\end{array}$ & $\begin{array}{r}52.7 \\
17.7 \\
7.6 \\
12.8 \\
9.2\end{array}$ \\
\hline 6 & $\begin{array}{l}\text { Organization Activities: } \\
\text { Food and Beverages } \\
\text { Tobacco Product } \\
\text { Textiles Materials } \\
\text { Weaving and Dyeing } \\
\text { Furniture and Equipment } \\
\text { Recycling } \\
\text { Poultry } \\
\text { Others }\end{array}$ & $\begin{array}{r}131 \\
23 \\
70 \\
55 \\
54 \\
36 \\
103 \\
42\end{array}$ & $\begin{array}{r}25.5 \\
4.5 \\
13.6 \\
10.7 \\
10.5 \\
7 \\
20 \\
8.2\end{array}$ \\
\hline 7 & $\begin{array}{l}\text { Total assets at the end of year: } \\
\text { Less than } 1 \text { million naira } \\
1-100 \text { million naira } \\
101-200 \text { million naira } \\
201-300 \text { million naira } \\
301 \text { million-Above }\end{array}$ & $\begin{array}{r}178 \\
225 \\
55 \\
30 \\
26\end{array}$ & $\begin{array}{r}34.6 \\
43.8 \\
10.7 \\
5.8 \\
5.1\end{array}$ \\
\hline
\end{tabular}

Table 1. Summary of respondents Demography

\subsection{Descriptive Analysis}

Table 2 reveals descriptive statistic for the perceived ethics, organizational culture and performance. The mean value of perceived ethics was relatively high than the mean value of organizational culture and performance which demonstrated to be 5.33 and 5.23 respectively. Hence, the result indicates the level of perceived ethics on performance of SMEs in Nigeria. 


\begin{tabular}{|l|r|r|r|r|r|}
\hline \multicolumn{1}{|c|}{ Constructs } & N & \multicolumn{1}{c|}{ Mean } & Standard deviation & \multicolumn{1}{c|}{ Minimum } & \multicolumn{1}{c|}{ Maximum } \\
\hline Perceived Ethics & 486 & 5.41 & 0.63 & 2 & 7 \\
\hline O.culture & 486 & 5.33 & 0.58 & 2 & 7 \\
\hline Performance & 486 & 5.23 & 0.69 & 1 & 7 \\
\hline
\end{tabular}

Table 2. Descriptive analysis

\subsection{The Measurement, Outer, Model}

This paper used PLS structural equation modelling (SEM) to calculate approximately its theoretical model using the software application SmartPLS (Hair, Hult, Ringle \& Sarstedt, 2013; Ringle, Wende \& Will, 2012). PLS SEM depends on two vital multivariate techniques including factor analysis, and multiple regressions (Hair, Black, Babin, Andersen \& Tatham, 2010). PLS tool is used throughout analysis of the main and mediating results for this study. Moreover, In PLS analysis, the first step is to evaluate the measurement model, or the outer model. Measurement model is focus with estimate the goodness of measure. Therefore, two main criteria are used in PLS analysis to evaluate the measurement model or what is otherwise called the outer model consist of validity and reliability (Ramayah, Lee \& In, 2011).

\subsubsection{The Content Validity}

Construct validity testifies to how well the results obtained from the use of the measure fit the theories around which the test is designed (Sekaran \& Bougie, 2010). In line with Hair et al. (2010) and Chin (1998a), factor loading of the items could be used to confirm the content validity of the measurement model. Further, all the items meant to measure a particular construct should load highly on the construct they were designed to measure. If some items load on some other factors higher than their respective construct, these items will be candidate for deletion (Hair et al., 2010).

In addition, all the measures of the construct should be significantly loaded on their respective construct. As illustrated in (Table 3), all the items load highly and significantly on the constructs they were designed to measure. Thus, the content validity of the measurement, outer, model was confirmed, for example, this study used a cutoff value for loadings at 0.5 as significant (Hair et al. 2010, 2013). Therefore, if any items which have a loading of higher than 0.5 on two or more factors then they will be deemed to be having significant cross loadings. From Table 3 we can observe that all the items measuring a particular construct loaded highly on that construct and loaded lower on the other constructs thus confirming construct validity. 


\begin{tabular}{|l|r|r|l|}
\hline Constructs & \multicolumn{1}{|c|}{ Pethics } & \multicolumn{1}{|c|}{ OCulture } & Performance \\
\hline PE03 & 0.695 & & \\
\hline PE04 & 0.698 & & \\
\hline PE05 & 0.743 & & \\
\hline PE06 & & 0.740 & \\
\hline BU08 & & 0.668 & \\
\hline IN10 & & 0.677 & \\
\hline IN11 & & 0.635 & \\
\hline IN13 & & 0.652 & \\
\hline IN14 & & 0.633 & \\
\hline IN16 & & 0.665 & \\
\hline SP17 & & 0.673 & \\
\hline SP20 & & 0.714 & 0.980 \\
\hline SP22 & & 0.676 & \\
\hline SP23 & & 0.650 & \\
\hline SP24 & & & \\
\hline OP05 & & & \\
\hline OP06 & & & \\
\hline OP07 & & & \\
\hline
\end{tabular}

Table 3. Construct Validity

The average variance extracted (AVE) ranged from .430,518 and .670 respectively, confirming convergent validity and implicitly, content validity except organizational culture is closed to yardstick. Composite reliabilities ranged from Perceived Ethics .811, organizational culture, .890 and Performance .856 demonstrating reliability for all constructs see Table 4. Table 5 also displays the results for the Fornell-Larcker procedure (Fornell \& Larcker, 1981) to assess discriminant validity. Discrimi-nant validity is satisfactory for constructs, the result was not unexpected. However, since it represents a relationship between an exogenous construct and an endogenous construct. Examination of the indicators for these constructs shows the content in general is distinct from a face validity perspective as well as based on the literature (Curras-Pérez et al., 2009; Tian et al., 2011; Valentine \& Fleischman, 2008). In sum, the two-construct model was considered satisfactory in terms of content and convergent validity, discriminant validity, and composite reliability. 


\begin{tabular}{|c|c|c|c|c|c|}
\hline Variable & Indicator & Loading & Cronbach alpha & Composite reliability (CR) & AVE \\
\hline \multirow{4}{*}{$\begin{array}{l}\text { Perceived } \\
\text { Ethics }\end{array}$} & PE03 & 0.605 & 0.691 & 0.811 & 0.518 \\
\hline & PE04 & 0.698 & & & \\
\hline & PEO5 & 0.743 & & & \\
\hline & PE06 & 0.740 & & & \\
\hline \multirow{11}{*}{ O. Culture } & BU08 & 0.500 & 0.865 & 0.890 & 0.430 \\
\hline & IN10 & 0.668 & & & \\
\hline & IN11 & 0.677 & & & \\
\hline & IN13 & 0.635 & & & \\
\hline & IN14 & 0.652 & & & \\
\hline & IN16 & 0.633 & & & \\
\hline & SP17 & 0.665 & & & \\
\hline & SP20 & 0.673 & & & \\
\hline & SP22 & 0.714 & & & \\
\hline & SP23 & 0.676 & & & \\
\hline & SP24 & 0.650 & & & \\
\hline \multirow{3}{*}{ Performance } & OP05 & 0.473 & 0.749 & 0.856 & 0.670 \\
\hline & OP06 & 0.893 & & & \\
\hline & OP07 & 0.809 & & & \\
\hline
\end{tabular}

Table 4. Reliability and Validity of Constructs

\begin{tabular}{|l|r|r|r|}
\hline \multicolumn{1}{|c|}{ Constructs } & OCulture (2) & Performance (2) & \multicolumn{2}{|c|}{ PEthics (3) } \\
\hline OCulture (1) & $\mathbf{0 . 6 5 6}$ & & \\
\hline Performance (2) & 0.628 & $\mathbf{0 . 8 1 9}$ & \\
\hline PEthics (3) & 0.589 & 0.623 & $\mathbf{0 . 7 2 0}$ \\
\hline
\end{tabular}

Note: Diagonals (in bold) represent the average variance extracted while the other entries represent the squared correlations matrix.

Table 5. Fornell-Larker Discriminant validity

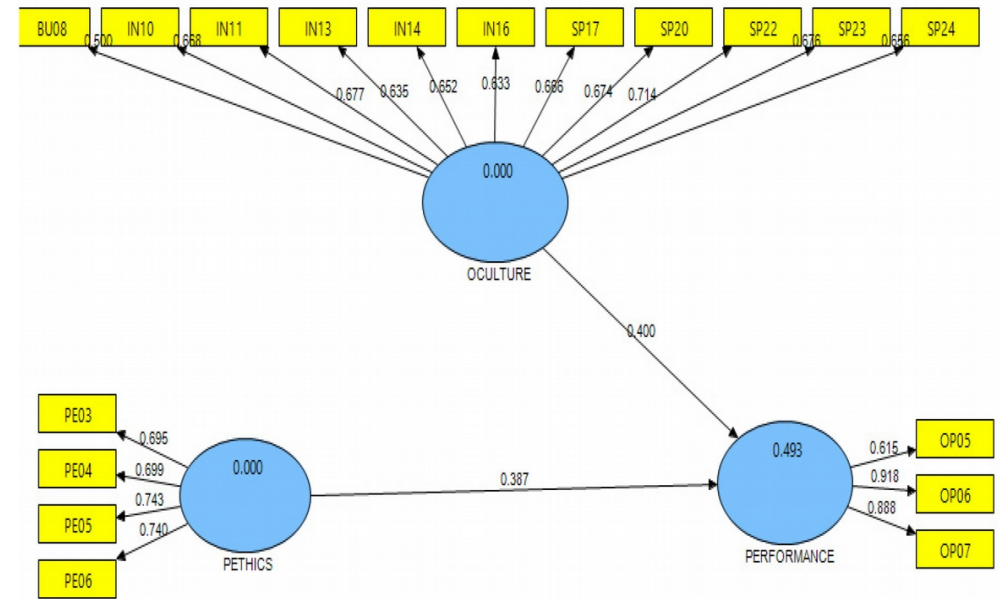

Figure 2. Measurement Model 
The next step in SEM-PLS is to analyze the structural model. Figure 3 shows the model tested. The structural model was explained by Table 6 and Figure 3. The R square value was 0.49 which suggest that the model variable can explain $49 \%$ of the variance of the dependent variable which is substantial (Cohen, 1988). Hypotheses 1 stated that Perceived ethics was significantly related to a dependent variable business performance the result in Table 6 and Figure 3, shows that hypotheses 1 is supported (beta=0.387; $\mathrm{t}=8.215 ; \mathrm{p}<0.001)$. This result showed the significance of perceived ethics for an improved business performance and thus supported H1 of the study. Similarly, relationship between Organizational culture and Performance is also significant (beta $=0.400 ; \mathrm{t}=7.771 ; \mathrm{p}<0.001) \mathrm{H} 2$ is accepted, equally organizational culture mediates the relationship between perceived ethics and performance (beta $=0.378 ; \mathrm{t}=7.845$; $\mathrm{p}<0.001$ ), thus $\mathrm{H} 3$ is accepted.

\begin{tabular}{|c|c|c|c|c|c|}
\hline Hypotheses & Path coefficient & Standard error & T. value & P. value & Decision \\
\hline $\mathrm{PE}->\mathrm{OP}$ & 0.387 & 0.047 & 8.215 & 0.001 & Supported \\
\hline OC -> OP & 0.400 & 0.052 & 7.771 & 0.001 & Supported \\
\hline $\mathrm{PE}->\mathrm{OC}->\mathrm{OP}$ & 0.378 & 0.048 & 7.845 & 0.001 & Supported \\
\hline
\end{tabular}

Table 6. Hypothesis testing

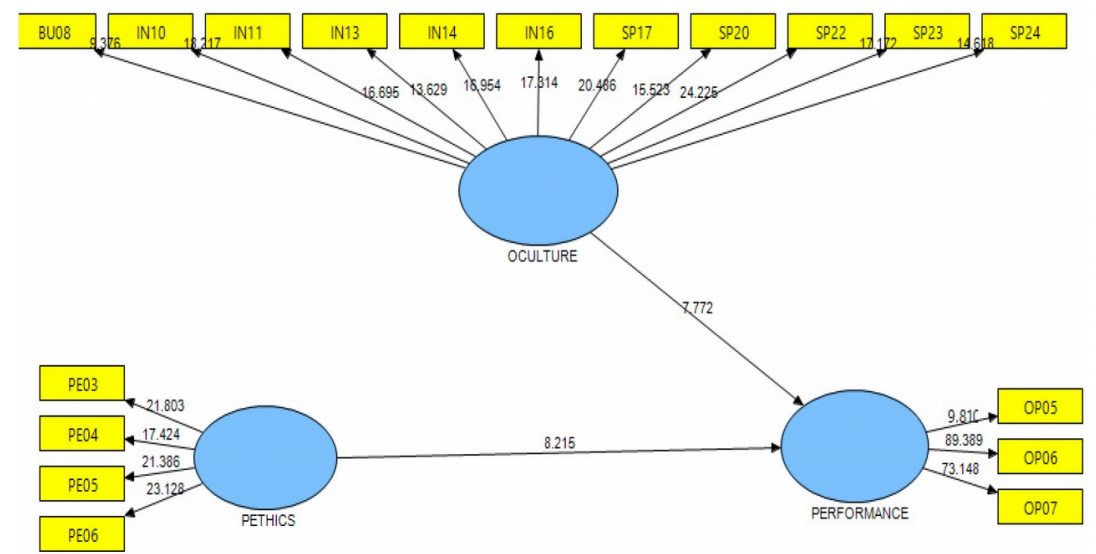

Figure 3. Structural Model

\subsection{Mediation Test}

Mediation test is conducted to discover if a mediator construct can significantly carry the ability of an independent variable to a dependent variable (Ramayah et al., 2011). Similarly, mediation test determine the indirect effect of the independent variable on the dependent variable through a mediator variable. In addition, in study of Hayes and Preacher (2010) examine that mediation analysis in multivariate analysis is determine through many techniques including: (1) simple techniques that consist of the causal steps 
approach (Baron \& Kenny, 1986) or the Sobel test (Sobel, 1982); (2) newer approaches that demand just fewer unrealistic statistical assumptions. Among other include the distribution of the product method (MacKinnon, Lockwood \& Williams, 2004), and re-sampling approaches such as bootstrapping (Bollen \& Stine, 1990; Preacher \& Hayes, 2004, 2008; Shrout \& Bolger, 2002). Significantly, the mediation test used for this paper was based on the PLS approach, hence, the hypotheses for the study were tested using the partial least squares (PLS) structural equations modeling (SEM) technique (Wold, 1985). And mediation test is measured by means of bootstrapping 5000 re-sampling analysis in with formulated hypotheses (Hair, Ringle \& Sarstedt, 2011; Zhao, Lynch \& Chen, 2010). In addition, mediation is measured by multiplying the average of paths " $a$ " and " $b$ " and then dividing the obtained value by the standard error of the paths (Kock, 2013). (See Table 6 for this result and Figure 4).

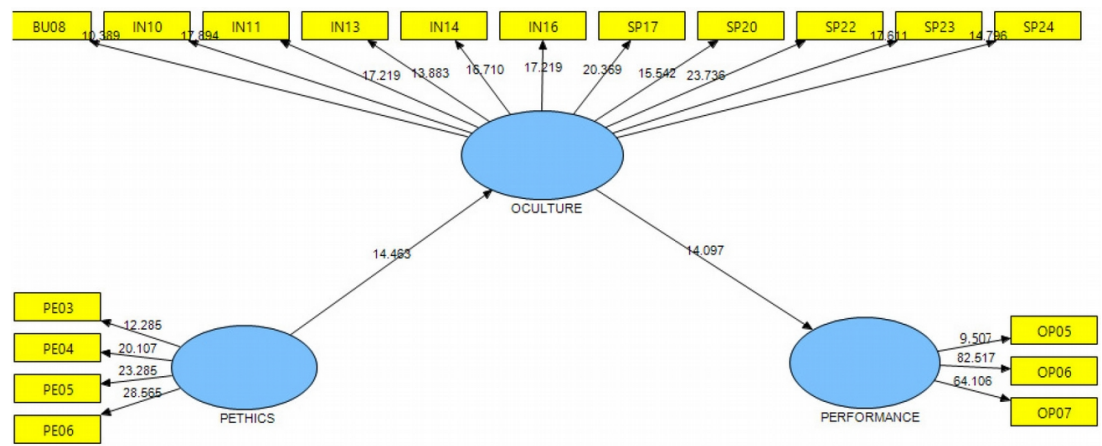

Figure 4. Mediation bootstrapping

\subsection{Predictive Relevance}

Furthermore, a cross-validated communality Q2 is obtained when the data points are predicted using the underlying latent variable scores. Whereas, if the prediction of the data points is obtained by the LVs that predict the block in question, then a cross-validated redundancy Q2 is the output. In line with recommendations by Fornell and Cha (1994), the model will have predictive quality if the crossredundancy value was found to be more than 0 , otherwise the predictive relevance of the model cannot be concluded. Based on the Smart PLS 2.0 results, the obtained cross validated redundancy was found to be 0.249 . Chin, (1998b), set three criteria

- if Q2 is 0.02 , then the model has small predictive relevance,

- if Q2 is 0.15 , then the model has medium predictive relevance, and

- if Q2 is 0.35 , then the model has large predictive relevance. This result supports the claim that the model has medium and an adequate prediction quality see Table 7. 


\begin{tabular}{|l|r|c|}
\hline Dependent variable & R square & Cross validated redundancy \\
\hline Performance & 0.49 & 0.249 \\
\hline
\end{tabular}

Table 7. Predictive relevance

\section{Discussion, Summary, Implication and Recommendation}

The statistically results recommend that there a reasonable significant relationship between perceived ethics and performance. The implication this finding is that the more SMEs perceives ethics and social responsibility the more they have positive performance which may likely have multiplier effect on GDP. Another meaning of this finding is that the more SMEs perceives business social responsibility programs this would likely enhance a firms performances. Like previous results, this finding is consistent with previous ones (Curras-Pérez et al., 2009; Berrone et al., 2007; Hilman \& Gorondutse, 2013; Sen \& Bhattacharya, 2001; Singhapakd et al., 1995; Tian et el., 2011; Torugsa, O’Donohue \& Hecker, 2012; Valentine \& Fleischman, 2008). In these studies, it was found that there is a significant relationship between perceive ethics and performance. In addition, in his survey on perceived BSR construct in United States, Hansen et al. (2011) found that the variable has a positive and significant relation on performance and turnover.

The second hypothesis state that Organizational culture is significantly related to Organizational Performance $(\mathrm{OC}->\mathrm{OP})$ is statistically significant with a Beta $(\beta)$ value and high t-value of above $1.96(\beta=0.400$, $\mathrm{t}=7.771, \mathrm{p}=0.001)$ and this results is consistent with Al-bahussin and El-garaihy (2013), Ali sha et al. (2011, 2005), Galbreath (2010), Larry et al. (2011) and Rashid et al. (2003) who reveal a positive association between organizational culture and performance. Consequently, the outcome of this research established that organizational culture significantly mediates the causal relationships between perceived ethics and performance hence $\mathrm{H} 3$ accepted. The finding also confirms that due awareness of social behavior by SMEs; organizational culture would have a mediating effect on their performance. To this end, this is hoped to have significantly contributed to management theory.

The results of this research can help practitioners to understand and present adequate indication for confirming a significant causal relationship. The findings were drawn based on the statistical results, and the practical recommendations were, in turn, derived logically from the findings. Managers/owners are provided with practical recommendations in order to have more insight regarding the implication of their perceived ethics and organizational culture vis-a-vis performance. Managers/owners should ensure that social responsibility behaviors given to stakeholders are continuous, good enough and in fact, tremendous. This would most likely improve their performance. This study reveals the significant causal relationship between organizational culture and performance. This implies that managers/owners and 
policy makers should be more concerned about the organizational culture (i.e., ethical culture). Put differently, managers/owners and policy makers should ensure that the organizational culture suits the social behavior which could lead to a favorable performance.

Additionally, perceived ethics was found to have a significant positive causal effect on performance. The implication of this is that the more managers/owners perceive that they receive benefits comparable to the resources they spend on social behavior, the more they continue to practice it, and this is consistent with Husted (2005) who explains that BSR may be viewed as real options. Again, this implies that policy makers should provide an appropriate way that stakeholders can perceive greater benefits than sacrifices they make to SMEs. Policy makers should also view the issues of ethical and social behavior through the lens of smaller firms as a means of creating viable benefit. Hatten (2006) argues that ethical and social behaviors in smaller firms should go hand-in-hand with the strategic planning of the organizations. Therefore, policy makers should try to make it possible for stakeholders to accomplished and receive social behaviors with less effort and in the shortest possible time. Balmer, Fukukawa and Gray (2007) and Hansen et al. (2011) suggest that organizations engaged in BSR initiatives should not limit such actions to external stakeholders only but also to employees to encourage positive BSR perceptions, linking them directly in the planning and execution of BSR actions.

Similarly, the result of this study will add value to existing literature on the relationship between perceived ethics on business performance particularly on issue related to social behavior. Secondly, this study contributed in the body of knowledge by testing stakeholder theory outside the context of Europe and USA firms thereby confirming the theory which postulate that business managers should tailor their policies in order to satisfy a number of stakeholders (Freeman, 1984). In addition, the present study also combine various past measurement studies in measuring the effect of perceived ethics on business performance this also could add to the body of knowledge within the context of this research.

\subsection{Conclusion, Limitations of Study and Suggestion for Future Studies}

This study is subject has some limitations, one constrain is the used of cross sectional design for survey research, thus, the study cannot establish causal relationship on a longitudinal basis. The finding cannot be generalized in larger context across the cultures of other countries since the data collected during the study was limited to Kano state, North West of Nigeria.

In this study an attempt was made to examined the influence of perceived ethics on business performance the results has confirm the significant of perceived ethics on business performances. Specifically, perceived ethics has proven to have a statistically significant effect on business performance, and account $49 \%$ of the variance in the business performance this result confirm the existing literature 
(see for instance Curras-Pérez et al. (2009), Berrone et al. (2007), Hilman and Gorondutse (2013), Tian et al. (2011), Torugsa et al. (2012) and Valentine and Fleischman (2008)). Finally In order to overcome the limitations of this study, future research should employed longitudinal approach of the study. In addition, the present study employed quantitative techniques future study can employed qualitative or case study method for design and analysis of information.

\section{References}

Adegbite, E., \& Chizu, N. (2011). Corporate governance and Responsibility in Nigeria. International journal of Disclosure and Governance, 8(3), 252-271. http://dx.doi.org/10.1057/jdg.2011.2

Aguilera, R., Ruth, V., Rupp, D., Williams, C., \& Ganapathi, J. (2007). Putting the S Back in Corporate Social Responsibility: A Multilevel Theory of Social. Change in Organizations, Academy of Management Review, 32, 836-863. http://dx.doi.org/10.5465/AMR.2007.25275678

Ahmad, K.Z., Veerapandian, K., \& Ghee, W. (2011). Person - Environment Fit: The missing Link in the Organizational Culture - Commitment Relationship. International Journal of Business and Management, 6(11), 11-20. http://dx.doi.org/10.5539/ijbm.v6n11p11

Akter, S.D., Ambra, J., \& Ray, P. (2011). An evaluation of PLS based complex models: The roles of power analysis, predictive relevance and GoF index. Proceedings of the Seventeenth Americas Conference on Information Systems, Detroit, Michigan. August.

Al-bahussin, S.A., \& El-garaihy, W.H. (2013). The impact of human resources mamagement practices, organizational culture, organization innovation, and knowledge management on organization performance in Saudi Organization Structural Equation Modeling with conceptual framework. International Journal of Business and management, 8(22), 1-19. http://dx.doi.org/10.5539/ijbm.v8n22p1

Amaeshi, K., Adi, B., Ogbechie, C. \& Amao, O. (2006). Corporate Social Responsibility in Nigeria: Western Mimicry or Indigenous influence? No 39, ICCSR Research paper series. ISSN 1479-5124. The University Nottingham. http://dx.doi.org/10.9774/gleaf.4700.2006.wi.00009

Aupperle, K., Carroll, A., \& Hatfield, J. (1985). An Empirical Examination of the Relationship between Corpo-rate Social Responsibility and Profit-ability. Academy of Management Journal, 28, 446-463. http://dx.doi.org/10.2307/256210

Bagozzi, R.P., Yi, Y., \& Phillips, L.W. (1991). Assessing construct validity in organizational research. Administrative Science Quarterly, 36(3), 421-458. http://dx.doi.org/10.2307/2393203 
Balmer, J.M.T., Fukukawa, K., \& Gray, E.R. (2007). The nature and management of ethical corporate identity: A commentary on corporate identity, corporate social responsibility and ethics. Journal of Business Ethics, 76, 7- 15.

Baron, R.M., \& Kenny, D.A. (1986). Moderator-mediator variable distinction in social psychological research: conceptual, strategic and statistical considerations. Journal of Personality and Social Psychology, 51(6), 1173-1182. http://dx.doi.org/10.1037/0022-3514.51.6.1173

Berrone, P., Surroca, J., \& Tribo, J.A. (2007). Corporate Ethical Identity as Determinant of Firm Performances: A Test of The Mediating Role of Stakeholder Satisfaction. Journal of Business Ethics, 76, 35-53. http://dx.doi.org/10.1007/s10551-006-9276-1

Bollen, K.A., \& Stine, R. (1990). Direct and indirect effects: Classical and bootstrap estimates of variability. Sociological Methodology, 20, 115-140. http://dx.doi.org/10.2307/271084

Carroll, A.B., \& Shabana, K.M. (2010). The business case for corporate social responsibility: A review of concepts research and practices. International Journal of Management Review, 12(1), 85-105. http://dx.doi.org/10.1111/j.1468-2370.2009.00275.x

Cavana, R., Delahaye, B.L., \& Sekaran, U. (2001).Applied Business Research: Qualitative and Quantitative Methods. Singapore: Markono Print Media, Ltd.

Chin, W.W. (1998a). The partial least squares approach for structural equation modeling. In Marcoulides, G.A. (Ed.). Modern Methods for Business Research. Mahwah, NJ: Lawrence Erlbaum Associates. 295-336.

Chin, W.W. (1998b). The Partial Least Squares Approach for Structural Equation Modeling, in Modern Methods for Business Research, (pp. 295-336)G.A. Marcoulides (Ed.), Mahwah, NJ: Lawrence Erlbaum Associates.

Chin, W.W., Marcolin, B.L., \& Newsted, P.R. (2003). A partial least squares latent variable modeling approach for measuring interaction effects. Results from a Monte Carlo simulation study and an electronic-mail emo-tion/adopion study. Information System Research, 14(2), 189-217. http://dx.doi.org/10.1287/isre.14.2.189.16018

Churchill, G.A., \& Peter, J.P. (1984). Research design effects on the reliability rating scales: A metaanalysis. Journal of Marketing Research, 21(4), 360-375. http://dx.doi.org/10.2307/3151463

Cochet, K. \& Chi, V.L. (2012). Impact of CSR Tools on SMEs: The case of Global Performance in France. International Business Research, 5(7), 50-55. 
Coffey, B., \& Fryxell, G. (1991). Institutional Ownership of Stock and Dimensions of Corporate Social Performance: An Empirical Examination. Journal of Business Ethics, 10, 437-444.

http://dx.doi.org/10.1007/BF00382826

Cohen, J. (1988). Statistical Power Analysis for Behavioral Sciences. 2nd Ed. Hillsdale, NJ: L. Erlbaum.

Curras-Pérez, R., Bigne, A.E., \& Herrera, A.A. (2009). The Role of Self-Definitional Principles in Consumer Identification with a Socially Responsible Company. Journal of Business Ethics, 89, 547-564. http://dx.doi.org/10.1007/s10551-008-0016-6

Dag, A.S. (2006). Leadership Practices and Organizational Performance- a Norwegian study. EDAMBA Journal.

David, O.A. (2012). An assessment of the impact of corporate social responsibility on Nigeria society: The examples of banking and communication industries. Universal Journal of Marketing and Business Research, 1(1), 017-043.

Deshpande, R., \& Farley, J. (1999). Executive insights: corporate culture and market Orientation: comparing Indian and Japanese firms. Journal of International Marketing, 7(4), 111-127.

Donaldson, T., \& Preston, L.E. (1995). The stakeholder theory of the corporation: concepts, evidence and implications. Academy of Management Review, 20(1), 65-91.

European Commission, (2003). Retrieved from: www.european commis-sion.org/2003.

Fang, S., Huang, C., \& Stephanie, W. (2010). Corporate social responsibility strategies, Dynamic capability and organizational performance: Cases of top Taiwan- selected Benchmark enterprises. African Journal of Business Management, 4(1), 120-132.

Fornell, C., \& Cha, J. (1994). Partial least squares. In R.P. Bagozzi (Ed.), Advanced methods of marketing research (pp. 52-78). Cambridge: Blackwell.

Fornell, C., \& Larcker, D.F. (1981). Evaluating structural equation models with unobservable and measurement error. Journal of Marketing Research, 18, 39-50. http://dx.doi.org/10.2307/3151312

Freeman, R.E. (1984). Strategic management: A stakeholder perspective. Englewood Cliffs, NJ: Prentice Hall.

Galbreath, J. (2010). Drivers of corporate social responsibility: The role of formal strategic planning and firm culture. British Journal of Management, 21, 511-525. 
Gorondutse, A.H., \& Hilman, H. (2014). Meditation Effect of Organizational Culture on the Relationship between Commitments of Business Social Responsibility (BSR) on Performance of SMEs: Partial Least Square (PLS) Approach. European Journal of Social Sciences, 41(4), 624-638

Haenlein, M. \& Kaplan, A.M. (2011). The In-fluence of Observed Heterog neity on Path Coefficient Significance: Tech-nology Acceptance Within the Mar-keting Discipline. Journal of Marketing Theory and Practice, 19(2), 153-168. http://dx.doi.org/10.2753/MTP1069-6679190203

Hair, J.F., Black, W.C., Babin, B.J., Andersen, R.E., \& Tatham, R.L.(2010). Multivariate data analysis. 7th Ed. Upper Saddle River, NJ: Pearson Prentice Hall.

Hair, JF., Hult, G.T.M., Ringle, C.M., \& Sarstedt, M. (2013). An primer on partial least squares structural equation modeling (PLS-SEM). London: Sage Publication.

Hair, J.F., Ringle, C.M., \& Sarstedt, M. (2011). PLS-SEM: Indeed a silver bullet. Journal of Marketing Theory and Practice,19(2), 139-151. http://dx.doi.org/10.2753/MTP1069-6679190202

Hair, J.F., Wolfinbarger, M.F., \& Ortinau, D.J. (2008). Essential of marketing research. Boston: McGraw-Hill/Irwin.

Hansen, S.D., Dunford, B.B., Boss, A.D., Boss, R.W., \& Angermeier, I. (2011). Corporate social responsibility and the benefits of employee trust: A cross-Disciplinary perspective. Journal of Business Ethics, 102, 29-45. http://dx.doi.org/10.1007/s10551-011-0903-0

Hatten, T.S. (2006). Small business management: Entrepreneurship and beyond (3rd ed.). New York: Houghton Mifflin Company.

Hayes, A.F., \& Preacher, K.J. (2010). Quantifying and testing indirect effects in simple mediation models when the constituent paths are nonlinear. Multivariate Behavioral Research, 45, 4, 627-660. http://dx.doi.org/10.1080/00273171.2010.498290

Herndon, N.C., Fraedrich, J.P., \& Jen-yeh, Q. (2001). An investigation of moral values and ethical content of corporate culture: Taiwan versus US Sales people. Journal of Business Ethics, 30, 73-85. http://dx.doi.org/10.1023/A:1006493907563

Hilman, H., \& Gorondutse, A.H. (2013). Relationship between perceived ethics and Trust of Business Social Responsibility (BSR) on performance of SMEs in Nigeria. Middle-East Journal of Scientific Research, 15(1), 36-45. 
Hulland, J. (1999). Use of partial least squares (PLS) in strategic management research: A review of four recent studies. Strategic Management Journal, 20, 195-204. http://dx.doi.org/10.1002/(SICI)10970266(199902)20:2<195::AID-SMJ13>3.0.CO;2-7

Husted, B.W. (2005). Risk management, real options and corporate social responsibility. Journal of Business Ethics, 60(2), 175-183. http://dx.doi.org/10.1007/s10551-005-3777-1

Ite, U.E. (2004). Multinationals and corporate social responsibility in developing Countries: a case study of Nigeria. Corporate Social Responsibility and Environmental Management, 11(1), 1-11. http://dx.doi.org/10.1002/csr.49

Ite, U.E. (2005). Poverty reduction in resource- rich developing countries: What have multinational corporations got to do with it?. Journal of international Development, 17, 913-929. http://dx.doi.org/10.1002/jid.1177

Jin, K.G., \& Drozdenko, R. (2010). Relationships among perceived or-ganizational core values, corporate social responsibility ethics, and or-ganizational performance outcomes: An empirical study of information technology professionals. Journal of Business Ethics, 92(3), 341-359.

http://dx.doi.org/10.1007/s10551-009-0158-1

Jin, K.G., Drozdenko, R., \& Deloughy, S. (2013). The role corporate value cluster in ethics, social responsibility and performance: A study of financial professional \& implication for the financial meltdown. Journal of business ethics, 112, 15-24. http://dx.doi.org/10.1007/s10551-012-1227-4

Jones, T.M. (1995). Instrumental stakeholder theory: A synthesis of ethics and economics. Academy of Management Review, 20(2), 404-437.

Joyner, B.E., \& Payne, D. (2002). Evolution and Implementation: A Study of Values, Business Ethics and Corporate Social Responsibility. Journal of Business Ethics, 41, 297-311.

http://dx.doi.org/10.1023/A:1021237420663

Kaplan, R.S., \& Norton, D.P. (1992). The Balanced Scorecard - Measures That Drive Performance, Harvard Business Review, 70(1), 71-79.

Kock, N. (2013). Advanced mediating effects tests, multi-group analyses, and measurement model assessments in PLS-based SEM. WarpPLS 3.0 User Manual. Laredo. Texas: ScriptWarp Systems.

Koh, H.C., \& Boh, E.H.Y. (2001). Or-ganisational ethics and employee sat-isfaction and commitment. Manage-ment Decision, 42(5), 677-693. 
Larry, Y., Morgan, N.A., \& Douglas, W.V. (2011). The Impact of Product Market StrategyOrganizational Culture fit on Business Performances. Journal of Academic of Marketing Sciences, 39, 555-573. http://dx.doi.org/10.1007/s11747-010-0238-x

Lin, C.P., Chen, S.C., Chiu, C.K., \& Lee, W.Yu. (2011). Understanding Purchase Intention During Product-Harm Crises: Moderating Effects of Perceived Corporate ability and Corporate Social Responsibility. Journal of Business Ethics, 102, 455-471. http://dx.doi.org/10.1007/s10551-011-0824-y

Lok, P. \& Crawford, J. (1999).The relationship between commitment and organizational culture, subculture, eadership style and job satisfaction in Organizational change and development. Leadership \&Organization Development Journal, 20(7), 365-373. http://dx.doi.org/10.1108/01437739910302524

Mackey, A., Mackey, T.B., \& Barney, J.B. (2007). Corporate social responsibility and firm performance: Investor preferences and corporate strategies. Academy of Management Review, 32(3), 817-835. http://dx.doi.org/10.5465/AMR.2007.25275676

MacKinnon, D.P., Lockwood, C.M., \& Williams, J. (2004). Confidence limits for the indirect effect: Distribution of the product and resampling methods. Multivariate Behavioral Research, 39, 99-128. http://dx.doi.org/10.1207/s15327906mbr3901_4

Nancy, P. \& Galanaki, E. (2008). Leadership's impact on employee engagement; Differences among entrepreneurs and professional CEOs. Leadership \& Organizational Development Journal, 30(4), 365-385.

Okoye, A. (2009). Theorising corporate social responsibility as an essentially contested concept: is a definition necessary? Journal of Business Ethics, 89(4), 613-627. http://dx.doi.org/10.1007/s10551-008-0021-9

Opara, O.J. (2010). Corporate Social Responsibility: An Analysis of perti-nent Issues, Challenges \& Opportuni-ties in Nigeria. Franklin Business \& Law journal, 4, 98-112.

Peloza, J., \& Papania, L. (2008). The Missing link Between Corporate Social Responsibility and Financial Performances: Stakeholder Salience and Identification. Corporate Reputation Review, 11(20), 169-181. http://dx.doi.org/10.1057/crr.2008.13

Peng-Lin, C., Chen, S., Chin, C., \& Lee, W. (2011). Understanding Purchase Intention During ProductHarm Crises: Moderating Effects of Per-ceived Corporate Ability and Corpo-rate Social Responsibility. Journal of Business Ethics, 102, 455-471. http://dx.doi.org/10.1007/s10551-011-0824-y

Perrini, F., \& Minoja, M. (2008). Strategizing corporate social respon-sibility: Evidence from an Italian me-dium-sized, family-owned company. Business Ethics: A European Review, 17(1), 47-63. http://dx.doi.org/10.1111/j.1467-8608.2008.00519.x 
Pivato, S., Misani, N., \& Tencati, A. (2008). The Impact of Corporate Social Responsibility on Consumer Trust: The Case of Organic Food. Business Ethics: A European Review, 17(1), 3-12. http://dx.doi.org/10.1111/j.1467-8608.2008.00515.x

Preacher, K.J., \& Hayes, A.F. (2004). SPSS and SAS procedures for estimating Indirect effects in simple mediation models. Behavior Research Methods, Instruments \& Computers, 36(4), 717-731. http://dx.doi.org/10.3758/BF03206553

Preacher, K.J., \& Hayes, A.F. (2008). Asymptotic and resampling strategies for assessing and comparing indirect effects in multiple mediator models. Behavior Research Methods, 40, 879-891. http://dx.doi.org/10.3758/BRM.40.3.879

Ramayah, T., Lee, J.W.C., \& In, J.B.C. (2011). Network collaboration and Performance in the tourism sector. Service Business, 5, 411-428. http://dx.doi.org/10.1007/s11628-011-0120-z

Rashid, M.Z.A., Sambasivan, M., \& Johari, J. (2003). The influence of corporate culture And organizational commitment on performance. Journal of Management Development, 22(8), 708-728. http://dx.doi.org/10.1108/02621710310487873

Ringle, C.M., Wende, S., \& Will, A. (2012). SmartPLS 2.0. Hamburg. Retrieved from: www.smartpls.de.

Schein, E.H. (1992). Organizational Culture and Leadership. 2nd Ed. San Francisco: Jossey-Bass.

Sen, S., \& Bhattacharya, C.B. (2001). Does Doing Good Always Lead to Doing Better? Consumer Reactions to Corporate Social Responsibility'. Journal of Marketing Research, 38(2), 225-243. http://dx.doi.org/10.1509/jmkr.38.2.225.18838

Sekaran, U., \& Bougie, R. (2010). Research methods for business. A skill building Approach. 5th Ed. UK: John Willey.

Shah, S.K.A., Iqbal, J.J., Razaq, A., Yameen, M., Sabir, S., \& Khan, M.A. (2011). Influential Role of Culture on Leadership Effectiveness and Organizational Performance. Information Management and Business Review, 3(2), 127-132.

Shrout, P.E., \& Bolger, N. (2002). Mediation in experimental and nonexperimental studies: New procedures and recommendations. Psychological Methods, 7(4), 422-445. http://dx.doi.org/10.1037/1082989X.7.4.422

Singhapakdi, A., Kraft, K.L., Vitell, S.J., \& Rallapalli, K.C. (1995). The Perceived Importance of Ethics and Social Responsibility on Organizational Effectiveness: A Survey of Marketers. Journal of the Academy of Marketing Science, 23, 49-56. http://dx.doi.org/10.1007/BF02894611 
Sobel, M.E. (1982). Asymptotic confidence intervals for indirect effects in structural Equation models. In Leinhardt, S. (Ed.). Sociological methodology. Washington, DC: American Sociological Association. 290-312. http://dx.doi.org/10.2307/270723

Stanaland, A.J.S., Lwin, M.O., \& Murphy, P.E. (2011). Consumer perception of the Antecedents and consequences of corporate social responsibility. Journal Business Ethics, 102, 47-55. http://dx.doi.org/10.1007/s10551-011-0904-z

Tabachnick, B.G., \& Fidell, L.S. (2007). Using multivariate statistics ( $5^{\text {th }}$ Ed.). Boston: Peason Education Inc.

Tian, Z., Wang, R., \& Yang, W. (2011). Consumer Responses to Social Responsibility (CSR) in China. Journal of Business Ethics, 101, 197-212. http://dx.doi.org/10.1007/s10551-010-0716-6

Torugsa, N.A., O'Donohue, W., \& Hecker, R. (2012). Capabilities, Proactive CSR and Financial Performance in SMEs: Empirical Evidence from an Australian Manufacturing Industry Sector. Journal of Business Ethics,109, 483-500. http://dx.doi.org/10.1007/s10551-011-1141-1

Trevino, L.K., \& Nelson, K.A. (2004). Managing Business Ethics: Straight Talk about How To Do It Right. $3^{\text {rd }}$ Ed. New York: John Wiley and Sons, Publishers.

Valentine, S., \& Fleischman, G. (2004). Ethics Training and Business persons' Perceptions of Organizational Ethics. Journal of Business Ethics, 52, 381-390. http://dx.doi.org/10.1007/s10551-004-5591-6

Valentine, S. \& Fleischman, G. (2008). Ethics Programs, Perceived Corporate Social Responsibility and Job Satis-faction. Journal of Business Ethics, 77,159-172. http://dx.doi.org/10.1007/s10551-006-9306-z

Verschoor, C.C. (1998). A Study of the link between a corporations financial Performances and its commitment to ethics. Journal of Business Ethics, 17, 1509-1516. http://dx.doi.org/10.1023/A:1006020402881

Venkatraman, N., \& Ramanujam, V. (1986). Measurement of business performance in strategy research: a comparison of approaches. Academy of Management Review, 1, 801-814.

Vitell, S.J., \& Davis, D.L. (1990). Ethical beliefs of MIS professionals: The frequency and opportunity for unethical behaviour. Journal of Busi-ness Ethics, 9, 63-70. http://dx.doi.org/10.1007/BF00382565

Wallach, E.J. (1983). Individuals and organizations: The cultural match. Training and Development Journal, 37, 29-36.

Waddock, S.A. \& Graves, S.B. (1997). The corporate social performance-financial performance link. Strategic Management Journal, 18(4), 303-319. http://dx.doi.org/10.1002/(SICI)1097-0266(199704)18:4<303::AIDSMJ869>3.0.CO;2-G 
World Bank (2005). World Bank Development Report. Washington D.C.

Wold, H. (1985). Partial least squares. In: Kotz, S, \& Johnson, N.L. (Eds.). Encyclopaedia of statistical sciences, 6. New York, NY: Wiley. 581-591.

Wood, G. (2002). A Partnership model of corporate ethics. Journal of Business ethics, 40, 673. http://dx.doi.org/10.1023/A:1019990724275

Yamane, T. (1967). Statistics: An Introductory Analysis. $2^{\text {nd }}$ Ed. New York: Harper and Row.

Zaborek, P. (2014). CSR and Financial Performance: The Case of Polish Small and Medium Manufacturers. International Journal of Management and Economics, 43, 53-73. Retrieved from: http://www.sgh.waw.pl/ijme/

Zhao, X., Lynch, J.G., \& Chen, Q. (2010). Reconsidering Baron and Kenny: Myths and truths about mediation analysis. Journal of Consumer Research, 37, 197-206. http://dx.doi.org/10.1086/651257

Journal of Industrial Engineering and Management, 2016 (www.jiem.org)

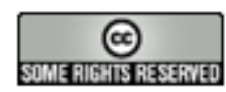

Article's contents are provided on an Attribution-Non Commercial 3.0 Creative commons license. Readers are allowed to copy, distribute and communicate article's contents, provided the author's and Journal of Industrial Engineering and Management's names are included. It must not be used for commercial purposes. To see the complete license contents, please visit http://creativecommons.org/licenses/by-nc/3.0/. 